\title{
The regulatory and Health Technology processes in Europe and drug market access. The case of cystic fibrosis
}

\author{
Mayra Latorre Martinez ${ }^{1}$, Pedro Serrano ${ }^{2,3}$, Antonio Sarria Santamera ${ }^{3,4,5}$ \\ Universidad Nacional de Educación a Distancia (UNED) \\ Servicio de Evaluación, Servicio Canario de Salud, El Rosario. Tenerife \\ 3 Red de Investigación en Servicios Sanitarios y Enfermedades Crónicas (REDISSEC) \\ Agencia de Evaluación de Tecnologías Sanitarias, Instituto de Salud Carlos III, Madrid, Spain \\ Universidad de Alcalá, Madrid, Spain
}

\begin{abstract}
In order to reach the European market, a new drug needs to receive a positive evaluation regarding its quality, safety and efficacy by regulatory health authorities and also obtain a positive HTA appraisal regarding its cost-effectiveness by HTA bodies. Regulators and HTA bodies are collaborating in several projects at European level in order to harmonize the scientific requirements of both evaluations to the maximum extent possible. The comparison of the regulatory evaluation performed by EMA for Kalydeco and the HTA appraisals issued by several EU bodies exemplifies the dilemma between scientific evidence and local economic considerations and the difficulties in the achievement of harmonization and therefore equity in the access to drugs.
\end{abstract}

Keywords

Cystic Fibrosis; Agencies/organization \& administration; Health Technology Assessment

\section{INTRODUCTION}

Health authorities assess the quality, safety and efficacy of a medicinal product ${ }^{1}$ based on its own merits whereas Health Technology Assessment (HTA) bodies evaluate the safety and efficacy of a drug comparatively to other available treatments on the market, as well as its cost-effectiveness. As a consequence, industry faces the challenge that the data set required to undertake the two evaluations could not be necessarily the same. In such a context, it is of extreme importance to design correctly from the start the expensive clinical programs with the aim of fulfilling the obligations for the two areas of assessment efficiently and in parallel.

European health authorities, including regulatory and HTA bodies, recognizing all these challenges and the existing room for harmonization have initiated the path towards knowledge sharing and collaboration in order to reach and establish common approaches.

The terms medicinal product, medicine and drug are used as synonyms.
The approval of medicinal products is a highly regulated field. The birth of the unified European legislation of medicines took place in 1965 with the adoption of Directive 65/65/ CEE [1]. The sponsor of any new medicinal product should demonstrate the quality, the safety and the efficacy of a drug prior to being granted the permission by the relevant health authorities to put the product on the market at the disposal of patients. The European Medicines Agency (EMA), the scientific body responsible for performing the evaluation, provides a scientific opinion to the European Commission (EC), which will then serve as the basis for the marketing authorization, which will have automatic validity in all European Union (EU) member states.

HTA is taking more and more relevance every day, for authorities, for payers and for industry. Proven quality, safety and efficacy, the three basic guarantees are no longer enough to allow patients access to a new medicine. Now, a medicinal product also has to demonstrate its relative cost-effectiveness, when compared to other available treatments, the so-called fourth guarantee in order to receive
Corresponding author Mayra Latorre Martinez maylatorre@yahoo.es

\section{Disclosure}

The authors have no conflicts of interest to declare. 
a positive appraisal by HTA bodies and successful reimbursement negotiations.

An important milestone has been reached in Europe in this context with the establishment of the European Union Network of HTA (EUnetHTA) [2]. In 2004, the EC and the Council of the EU recognized the Health Technology Assessment as a high priority and urged for establishing a sustainable European network on HTA. In 2005, a group of 35 organizations throughout Europe began the activities of the EUnetHTA Project. One of the most important milestones achieved by EUnetHTA is the creation of a Core harmonized Model for HTA appraisals, where the key elements to be evaluated by HTA bodies are represented [3]. As a response to the recommendations from the Pharmaceutical Forum in 2008, the EMA and EUnetHTA initiated a collaboration to improve the contribution that European Public Assessment Reports (EPARs) prepared by EMA could make to the assessment of relative effectiveness of medicinal products [4].

The EU Directive 2011/24/EU [5] on the application of patients' rights in cross-border healthcare set a milestone in the recognition of equity in rights across European Union Members States and also introduced important provisions for the EU collaboration in the area of rare diseases and HTA.

Kalydeco (ivacaftor), is recognized as being the first in a new class of medicines: Cystic Fibrosis Transmembrane Conductance Regulator (CFTR) potentiators. It targets the cystic fibrosis CFTR and so treats the underlying cause of the disease. It increases the time that activated CFTR channels remain open at the cell surface. Kalydeco is one the drugs that has received orphan designation for cystic fibrosis [6] and one of the seven drugs [7] for which the European Medicines Agency has adopted a positive opinion for cystic fibrosis. Kalydeco is at the moment one of the most expensive drugs in Europe. The annual price of the drug per patient makes it difficult to for some national budgets to absorb the cost [8]. The objective of this study was on the one hand to identify the elements that regulators and HTA bodies took into account when performing their respective evaluations of Kalydeco. And, on the other hand, to ascertain the origin of the divergent opinions identified among HTA bodies when confronted with the same clinical evidence.

\section{METHODOLOGY}

The EPAR for Kalydeco issued by the EMA in 2012 was taken as the reference document for the regulators evaluation [9].
The publicly available HTA appraisals in English, Spanish and German from European HTA bodies were taken as reference for this analysis. The selected reports correspond to the following HTA bodies ${ }^{2}$ :

- Scottish Medicines Consortium (SMC) UK Scotland [10];

- NHS England statement (NHS) - UK England [11];

- Therapeutic Positioning Report for Spanish Government (IPT) - Spain [12];

- Institut für Qualität und Wirtschaftlichkeit im Gesundheitswesen (IQWIG) Germany [13];

- National Center for Pharmacoeconomics (NCPE) - Ireland [14];

- Haute Autorité de Santé (HAS) - France [15].

A comparative analysis of the information contained in the EPAR and the HTA reports was undertaken following the 3 steps scheme described below:

1. Analysis following the HTA Core Model developed by EUnetHTA to determine the domains common to the regulatory and HTA fields;

2. Analysis of the study design elements which are frequently source of discrepancies between regulators and HTA bodies (i.e. comparators, study population and endpoints);

3. Analysis of the clinical evidence elements available pre-approval. The items considered were the benefit/risk balance, post-approval studies, degree of uncertainty and clinical added value. Study of the similarities and differences in the opinions among HTA bodies in view of the same clinical evidence which is taken from the EPAR published by the EMA ${ }^{3}$.

\section{RESULTS}

Each table contains a summary of the information present in the EPAR and HTA reports studied. The EUnetHTA Core Model (Table I) defines the domains that HTA bodies should study for their appraisals. Not all these domains are relevant for the regulatory assessment. In addition, the analysis showed that not all HTA reports considered all domains and also the depth and detail in which the same domains were addressed was different too.

\footnotetext{
All these HTA bodies have an advisory role but are not the ultimate decision maker in their respective countries

3 The clinical studies considered as sources of information were the same both in the EPAR and in the HTA reports (i.e. STRIVE, ENVISION and PERSIST). HTA bodies had more data (i.e. longer periods) from PERSIST study available at the time of appraisal than EMA.
} 
The analyses showed that the clinical study design was considered appropriate in all HTA reports (Table II). No divergent opinions in this area were pointed out between regulators and HTA bodies. The elements analysed under this area showed differences in opinions among HTA bodies, indicating variations in the acceptance of the degree of uncertainty regarding the long-term safety and efficacy. From the six HTA reports studied, four countries acknowledged the uncertainty present but accepted it. Two bodies, the NCPE of Ireland and the SMC of Scotland did not.
The appraisal of the clinical added value (i.e. relative cost effectiveness) also varies among HTA bodies (Table III). No discussion at all is present in the French and Spanish reports. In the German report only global budget considerations are present. The English, Scottish and Irish reports address the pharmacoeconomic studies provided by the Sponsor together with Incremental Cost Effectiveness Ratio (ICER) and Quality Adjusted Life Year (QALY) threshold elements in addition to global budget considerations.

\begin{tabular}{|c|c|c|}
\hline Elements & $\begin{array}{l}\text { EPAR Information: } \\
\text { What is sought to grant a } \\
\text { Marketing Authorization? }\end{array}$ & $\begin{array}{l}\text { HTA Reports Information: } \\
\text { What is sought for pricing and reimbursement? }\end{array}$ \\
\hline $\begin{array}{l}\text { Health problem } \\
\text { and current use }\end{array}$ & $\begin{array}{l}\text { D. Main elements of the disease } \\
\text { described. }\end{array}$ & $\begin{array}{l}\text { NHS: D. Estimation of number of patients eligible provided }(\approx 270) \text {. } \\
\text { SMC: D. Estimation of number of patients eligible provided }(\approx 70) \text {. } \\
\text { IPT: D. Estimation of number of patients eligible provided }(\approx 16) \text {. } \\
\text { NCPE: D. Estimation of number of patients eligible provided }(\approx 120) \text {. } \\
\text { HAS: D. Estimation of number of patients eligible provided }(\approx 74) \text {. } \\
\text { IQWIG: D. Estimation of number of patients eligible provided }(\approx 180) \text {. }\end{array}$ \\
\hline $\begin{array}{l}\text { Description } \\
\text { and technical } \\
\text { characteristics }\end{array}$ & $\begin{array}{l}\text { D. Main elements: } \\
\text { Marketing authorization (MA) date } \\
\text { Indication } \\
\text { Posology }\end{array}$ & $\begin{array}{l}\text { NHS: D } \\
\text { SMC: D } \\
\text { IPT: D } \\
\text { NCPE: D } \\
\text { HAS: D } \\
\text { IQWIG: D }\end{array}$ \\
\hline Safety & $\begin{array}{l}\text { D. The most frequent adverse } \\
\text { reactions were not severe and well } \\
\text { tolerated. }\end{array}$ & $\begin{array}{l}\text { NHS: ND } \\
\text { SMC: D. Based on EPAR. } \\
\text { IPT: D. Based on EPAR. The two post-authorisation measures } \\
\text { imposed on the MA mentioned as source of further information. } \\
\text { NCPE: ND } \\
\text { HAS: D. Based on EPAR. } \\
\text { IQWIG: ND. }\end{array}$ \\
\hline $\begin{array}{l}\text { Clinical } \\
\text { effectiveness }\end{array}$ & $\begin{array}{l}\text { D. Observational studies imposed } \\
\text { as a condition on the marketing } \\
\text { authorization. } \\
\text { Details discussed in Tables II and III. }\end{array}$ & $\begin{array}{l}\text { NHS: D. Details discussed in Tables II and III. } \\
\text { SMC: D. Details discussed in Tables II and III. } \\
\text { IPT: D. Details discussed in Tables II and III. } \\
\text { NCPE: D. Details discussed in Tables II and III. } \\
\text { HAS: D. Details discussed in Tables II and III. } \\
\text { IQWIG: ND. }\end{array}$ \\
\hline $\begin{array}{l}\text { Costs and } \\
\text { economic } \\
\text { evaluation }\end{array}$ & NA. & $\begin{array}{l}\text { NHS: D. Details discussed in Tables II and III. } \\
\text { SMC: D. Details discussed in Tables II and III. } \\
\text { IPT: ND. } \\
\text { NCPE: D. Details discussed in Tables II and III. } \\
\text { HAS: ND. } \\
\text { IQWIG: D. Details discussed in Tables II and III. }\end{array}$ \\
\hline Ethical analysis & NA. & $\begin{array}{l}\text { NHS: D. First drug in class. Severity of the disease. Improvement of } \\
\text { health, reduction of hospitalizations. Indicated for children when the } \\
\text { damage in tissues could be still slowed down. Mention to the fact that } \\
\text { similar ultra-orphan drugs previously financed with similar ICER ranges. } \\
\text { SMC: D. First drug in class. Incurable disease. } \\
\text { IPT: D. First drug in class. } \\
\text { NCPE: D. First drug in class. } \\
\text { HAS: D. First drug in class. } \\
\text { IQWIG: ND. }\end{array}$ \\
\hline $\begin{array}{l}\text { Organizational } \\
\text { aspects }\end{array}$ & $\begin{array}{l}\text { D. The medicine was authorized } \\
\text { subject to restricted medical } \\
\text { prescription (i.e. by specialists) and } \\
\text { subject to genetic diagnosis of the } \\
\text { mutation. } \\
\text { Monitoring system by registries. }\end{array}$ & $\begin{array}{l}\text { NHS: D. Genetic diagnosis required and sweat chloride levels } \\
\text { controls. Prescribed by specialists. Health outcomes to be monitored } \\
\text { by cystic fibrosis registries. } \\
\text { SMC: D. Based on EPAR indication. } \\
\text { IPT: D. Based on EPAR indication. } \\
\text { NCPE: ND. } \\
\text { HAS: D. Based on EPAR indication. } \\
\text { Hospital use. } \\
\text { IQWIG: ND. }\end{array}$ \\
\hline
\end{tabular}




\begin{tabular}{lll} 
> follow & \\
\hline Social aspects & NA. ND. \\
& & SMC: ND. \\
& & IPT: ND. \\
& NCPE: ND. \\
& HAS: ND. \\
& IQWIG: ND. \\
& NHS: ND. \\
Legal aspects & SMC: ND. \\
& IPT: ND. \\
& NCPE: ND. \\
& HAS: ND. \\
& IQWIG: ND. \\
\hline
\end{tabular}

Table I. EUnetHTA Core Model

$\mathrm{D}=$ element discussed in the report (i.e EPAR/HTA; HAS = Haute Autorité de Santé; IPT = Therapeutic Positioning Report for Spanish Government;

$I Q W I G=$ Institut für Qualität und Wirtschaftlichkeit im Gesundheitswesen; NA = not applicable to the evaluation; ND = element not discussed in the report (i.e. EPAR/HTA); NCPE = National Center for Pharmacoeconomics; NHS = NHS England statement; SMC = Scottish Medicines Consortium

\begin{tabular}{|c|c|c|}
\hline Elements & $\begin{array}{c}\text { EPAR Information: } \\
\text { What is sought to grant a Marketing } \\
\text { Authorization? }\end{array}$ & $\begin{array}{l}\text { HTA Reports Information: } \\
\text { What is sought for pricing and reimbursement? }\end{array}$ \\
\hline $\begin{array}{l}\text { Comparators } \\
\text { Placebo vs. Active }\end{array}$ & $\begin{array}{l}\text { D. Kalydeco was compared to placebo in two } \\
\text { Phase III pivotal trials (double-blind, randomized, } \\
\text { multicentre): } \\
\text { STRIVE on adults (VX08-770-102) and ENVISION } \\
\text { on children } \\
\text { (VX08-770-103) } \\
\text { The Standard of Care (SOC) (i.e. pre-study } \\
\text { medication) was continued in the patients with } \\
\text { the exception of the inhaled hypertonic saline, } \\
\text { which was not allowed. }\end{array}$ & $\begin{array}{l}\text { NHS: D. Statement that } 2 \text { well conducted research } \\
\text { studies (one in adults/one in children) placebo- } \\
\text { controlled trials were undertaken. Only palliative } \\
\text { treatments are currently available. } \\
\text { SMC: D. Superiority over placebo showed. There } \\
\text { are no comparators for the disease. } \\
\text { IPT: D. Currently only symptomatic treatments are } \\
\text { available. } \\
\text { NCPE: ND. } \\
\text { HAS: D. Currently only symptomatic treatments are } \\
\text { available. } \\
\text { IQWIG: ND. }\end{array}$ \\
\hline $\begin{array}{l}\text { Study population } \\
\text { Homogeneous vs. } \\
\text { Heterogeneous }\end{array}$ & $\begin{array}{l}\text { D. Two main studies involving } 219 \text { patients with } \\
\text { cystic fibrosis who had the G551D mutation in } \\
\text { at least one allele of the CFTR gene: one of the } \\
\text { studies was in patients }>12 \text { years old ( } \mathrm{n} .=167) \\
\text { (STRIVE), the other study involved patients } \\
\text { between } 6 \text { and } 12 \text { years ( } \mathrm{n} .=52 \text { ) (ENVISION). In } \\
\text { addition, patients included had a FEV } \mathrm{FE}_{1} \geq 40 \% \\
\text { and a minimum body weight of } 15 \mathrm{~kg}^{1} \text {. }\end{array}$ & $\begin{array}{l}\text { NHS: ND. } \\
\text { SMC: D. The small size is acknowledged as } \\
\text { appropriate considering the low number of patients } \\
\text { affected by the mutation. } \\
\text { IPT: D. The small size is acknowledged as } \\
\text { appropriate considering the low number of patients } \\
\text { affected by the mutation. } \\
\text { NCPE: ND. } \\
\text { HAS: D. Based on EPAR. } \\
\text { IQWIG: ND. }\end{array}$ \\
\hline $\begin{array}{l}\text { Endpoints (Patient } \\
\text { Reported Outcomes - } \\
\text { PROs, Quality of Life } \\
\text {-QoL, Duration of Life, } \\
\text { etc.). }\end{array}$ & 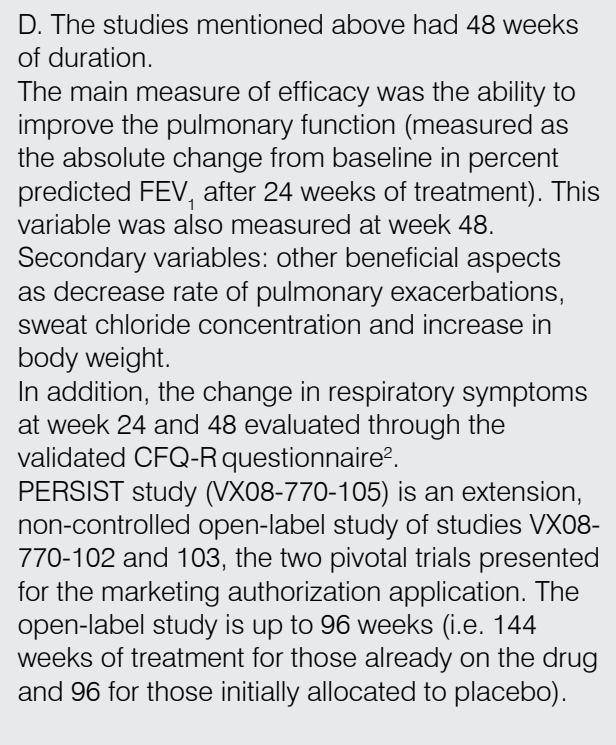 & $\begin{array}{l}\text { NHS: D. Improved lung function, weight gain } \\
\text { and decrease in worsening of breathing requiring } \\
\text { other treatments. Note is made to the absence of } \\
\text { long-term efficacy data but it is recognized that } \\
\text { the main indicator of cystic fibrosis, the amount of } \\
\text { salt in sweat returns to normal values with ivacaftor } \\
\text { treatment). } \\
\text { Indication of the extension, non-controlled open- } \\
\text { label study up to } 96 \text { weeks. } \\
\text { SMC: D. Acknowledgement of FEV }{ }_{1} \text { as a surrogate } \\
\text { which is the recommended primary clinical endpoint } \\
\text { for efficacy studies. CFQ-R mentioned. PERSIST } \\
\text { study (up to } 96 \text { weeks) also mentioned. } \\
\text { IPT: D. Based on EPAR. Indication of the extension, } \\
\text { non-controlled open-label study up to } 96 \text { weeks } \\
\text { (PERSIST). } \\
\text { NCPE: D. Brief reference to FEV, as primary } \\
\text { endpoint for Phase III clinical trials. } \\
\text { HAS: D. Based on EPAR. Indication of the } \\
\text { extension, non-controlled open-label study up to } 96 \\
\text { weeks (PERSIST). } \\
\text { IQWIG: ND. }\end{array}$ \\
\hline
\end{tabular}

\section{Table II Clinical Study Design}

${ }^{1} \mathrm{FVE} 1$ is the maximum amount of air that a person can breathe out in one second

${ }^{2} \mathrm{CFQ}-\mathrm{R}$ Questionnaire. In the CFQ-R, patients report respiratory symptoms. It is an indicator of the symptoms on the quality of life.

$\mathrm{D}=$ element discussed in the report (i.e EPAR/HTA; HAS = Haute Autorité de Santé; IPT = Therapeutic Positioning Report for Spanish Government;

$I Q W I G=$ Institut für Qualität und Wirtschaftlichkeit im Gesundheitswesen; NA = not applicable to the evaluation; ND = element not discussed in the report

(i.e. EPAR/HTA); NCPE = National Center for Pharmacoeconomics; NHS = NHS England statement; SMC = Scottish Medicines Consortium 


\begin{tabular}{|c|c|c|}
\hline Elements & $\begin{array}{c}\text { EPAR Information: } \\
\text { What is sought to grant a Marketing } \\
\text { Authorization? }\end{array}$ & $\begin{array}{l}\text { HTA Reports Information: } \\
\text { What is sought for pricing and reimbursement? }\end{array}$ \\
\hline $\begin{array}{l}\text { Positive benefit/risk balance } \\
\text { (Quality, Safety and Efficacy: } \\
\text { The } 3 \text { basic guarantees) }\end{array}$ & $\begin{array}{l}\text { D. } \\
\text { Quality: positive } \\
\text { Safety: positive. Minor side effects. } \\
\text { Efficacy: positive. } \\
\text { After } 24 \text { weeks of treatment, patients aged } \\
12 \text { years and older who took Kalydeco had } \\
\text { an average improvement in } \mathrm{FEV}_{1} \text { of } 10.4 \% \text {, } \\
\text { compared with a reduction of } 0.2 \% \text { in those } \\
\text { who took placebo. Similar results were } \\
\text { seen in patients aged between } 6 \text { and } 11 \\
\text { years, where Kalydeco treatment led to an } \\
\text { improvement in } \mathrm{FEV}, \mathrm{V}_{1} \text { of } 12.6 \% \text { compared } \\
\text { with an improvement of } 0.1 \% \text { with placebo. } \\
\text { These efficacy values were maintained at } \\
\text { week } 48 \text {. }\end{array}$ & $\begin{array}{l}\text { NHS: D. Based on EPAR. } \\
\text { SMC: D. Based on EPAR. } \\
\text { IPT: D. Based on EPAR. } \\
\text { Efficacy explicitly acknowledged. } \\
\text { NCPE: ND. } \\
\text { HAS: D. Based on EPAR. } \\
\text { IQWIG: ND. }\end{array}$ \\
\hline $\begin{array}{l}\text { Post-approval studies } \\
\text { (Generation of additional } \\
\text { evidence: PASS, PAES, } \\
\text { Registries). }\end{array}$ & $\begin{array}{l}\text { D. PASS and PAES imposed as a condition } \\
\text { of the Marketing Authorisation. Real world } \\
\text { data collection as part of these studies } \\
\text { required. }\end{array}$ & $\begin{array}{l}\text { NHS: D. Mention to PERSIST study. Mention that } \\
\text { health outcomes in patients taking ivacaftor will } \\
\text { be monitored using data from the cystic fibrosis } \\
\text { registry. } \\
\text { SMC: D. Long-term studies are acknowledged. } \\
\text { IPT: D. The studies imposed on the MA are } \\
\text { acknowledged and recognized as useful to clarify } \\
\text { pending long-term safety and efficacy evidence } \\
\text { generation. } \\
\text { NCPE: ND. } \\
\text { HAS: Discussed. Based on EPAR. } \\
\text { IQWIG: ND. }\end{array}$ \\
\hline $\begin{array}{l}\text { Degree of uncertainty } \\
\text { accepted }\end{array}$ & $\begin{array}{l}\text { D. } \\
\text { EPAR indicates limited data on longer-term } \\
\text { effects. } \\
\text { Conditions were imposed on the MA to } \\
\text { provide further data in this respect: } \\
\text { From an ongoing long-term study and to } \\
\text { conduct a five-year observational study. }\end{array}$ & $\begin{array}{l}\text { NHS: D. Good evidence that ivacaftor is } \\
\text { clinically effective although long-term safety and } \\
\text { effectiveness data beyond } 96 \text { weeks are lacking. } \\
\text { Monitoring of sweat chloride test required as } \\
\text { indicators of treatment effectiveness and used } \\
\text { as a stopping criteria for the treatment to be } \\
\text { discontinued. } \\
\text { SMC: D. The PERSIST study is acknowledged. } \\
\text { But long-term efficacy and safety data are } \\
\text { considered necessary for chronic conditions and } \\
\text { data beyond } 48 \text { weeks are limited. } \\
\text { IPT: D. Absence of long-term efficacy data to } \\
\text { prove maintenance of positive effects accepted. } \\
\text { Monitor the efficacy in patients receiving } \\
\text { treatment. } \\
\text { NCPE: D. Absence of long-term efficacy and } \\
\text { safety data not accepted. } 96 \text { weeks in adults and } \\
72 \text { in children considered limited. } \\
\text { HAS: D. Absence of long-term efficacy data to } \\
\text { prove maintenance of positive effects accepted. } \\
\text { IQWIG: ND. }\end{array}$ \\
\hline $\begin{array}{l}\text { Clinical added value } \\
\text { (Relative Cost-Effectiveness: } \\
\text { The 4th guarantee). }\end{array}$ & NA. & $\begin{array}{l}\text { NHS: D. ICER and QALY. No global budget } \\
\text { discussion. Ivacaftor reduces need for other } \\
\text { expensive treatments for progressive clinical } \\
\text { deterioration and need of hospital care, including } \\
\text { organ transplantation, which accounts for £100m } \\
\text { annual expenditure (excluding transplantation). } \\
\text { SMC: D. ICER, QALY and global budget figures } \\
\text { provided. } \\
\text { IPT: ND. } \\
\text { NCPE: D. ICER, QALY and general budget } \\
\text { considerations. Out of the accepted } 45000 \text { Euro/ } \\
\text { QALY threshold. } \\
\text { HAS: ND. } \\
\text { IQWIG: Global budget discussion. }\end{array}$ \\
\hline
\end{tabular}

Table III. Clinical evidence pre-approval

$\mathrm{D}=$ element discussed in the report (i.e EPAR/HTA; HAS = Haute Autorité de Santé; IPT = Therapeutic Positioning Report for Spanish Government; IQWIG = Institut für Qualität und Wirtschaftlichkeit im Gesundheitswesen; NA = not applicable to the evaluation; ND = element not discussed in the report (i.e. EPAR/HTA); NCPE = National Center for Pharmacoeconomics; NHS = NHS England statement; PAES: Post-Authorisation Efficacy Study; PASS: PostAuthorisation Safety Study; SMC = Scottish Medicines Consortium 


\begin{tabular}{lccccc}
\hline Country & Safety \& Efficacy & $\begin{array}{c}\text { Uncertainty } \\
\text { accepted }\end{array}$ & $\begin{array}{c}\text { Price and budget } \\
\text { considerations }\end{array}$ & $\begin{array}{c}\text { Recommendation } \\
\text { Final government } \\
\text { decision }\end{array}$ \\
\hline Spain & + & Yes & No & Positive & Positive \\
France & + & Yes & No & Positive & Positive \\
Germany & + & Yes & Yes & Positive & Positive \\
England & + & Yes & Yes & Positive & Positive \\
Scotland & + & No & Yes & Negative & Positive \\
Ireland & + & No & Yes & Negative & Positive \\
\hline
\end{tabular}

Table IV. Summary of key decision elements

\section{DISCUSSION}

From the point of view of the scientific evidence, all the HTA reports analysed obtained the main clinical elements regarding safety and efficacy from the published EPAR (Table IV). None of the HTA reports challenged the design of the studies or the clinical evidence generated.

However, there was a clear difference in the way the existing degree of uncertainty was evaluated, being this aspect the key point in the justification of the negative opinions reached by the Irish and Scottish HTA bodies.

All HTA reports alluded to the presence of uncertainty regarding long term effects. In fact, this aspect is well reflected in the EPAR. The EMA opinion noted the limited data on longer-term effects and as a result imposed conditions on the marketing authorization in this respect (provision of on-going long-term study and the conduct of a five-year observational study).

However, while for NHS England, Spain, France and Germany this degree of uncertainty was considered acceptable and did not preclude a positive financing decision, for the Scottish and Irish HTA bodies this represented the scientific clinical evidence factor highlighted and emphasized in order to support the negative opinion.

From a cost-effectiveness point of view, the Irish and Scottish HTA bodies were clear regarding that Kalydeco is not cost-effective. NHS England and Germany highlighted the high cost of the drug but still considered it financeable due to the characteristics of the drug and the illness. The Spanish and French HTA reports provided estimations to the number of patients eligible for the treatment in their respective countries but do not reported further on cost-effectiveness elements.

The HTA reports of NHS England, SCM and Ireland indicated the fact that the public administration engaged in price negotiations with the holder Vertex Pharmaceuticals or would be willing to do it in order to agree discounts that would facilitate the financing of this expensive treatment in their public health systems.

Nevertheless, despite the negative recommendations issued by the Scottish Medicines Consortium and the National Center for Pharmacoeconomics of Ireland, the governments of these two countries finally decided to make the drug available, being the decision ultimately raised to the political level.

It is also to be mentioned that outside the EU, similar conclusions were reached. The Canadian Drug Expert Committee (CDEC) recommended in March 2013 ivacaftor under the condition of a substantial reduction in price to meet cost-effectiveness criteria [16]. The Pharmaceutical Benefits Advisory Committee (PBAC) in Australia reflected in March 2014 that without a substantial price reduction or a pay for performance arrangement, ivacaftor would not be considered costeffective [17].

\section{CONCLUSION}

The case of Kalydeco exemplifies the dilemma between the scientific clinical evidence and the national budget considerations that HTA bodies face. Kalydeco was undoubtedly and unanimously recognized at EU level by regulators on the three first basic guarantees. However, the granting of an EU marketing authorization is not to be taken for granted as synonym of equal access to European patients. Some national HTA bodies can conclude that financing and reimbursement requirements are not met and therefore block entrance into their respective markets.

In such a situation, will the disharmony among European countries be solved if a common core HTA method and efficient sharing of data were established among HTA bodies? The example of Kalydeco evidences that the solution might not be so simple, as it is clear that the clinical evidence can be overruled by price and budget considerations.

In the last two decades, regulatory agencies have enormously increased the level of harmonization, communication and transpa- 
rency in relation to their assessment processes. HTA bodies in Europe are now working to achieve the same degree of harmonization and collaboration for HTA process and find a common path where both evaluation meet and align. However, the local focus that the financing perspective has cannot be obviated and as a result, different national conclusions can arise from the same clinical evidence. Some of them could be due to the selection of different factors for the analysis or the outcome of the importance and interpretation given based on local specificities and values or on national cost-effectiveness thresholds and budget's restrictions.

Regulators and HTA bodies are aware of the need to provide industry with clear guidelines for the development of new medicines and are willing to engage in a transparent and productive dialogue with industry in order to ensure predictability and facilitate as much as possible patient's early access to new medicines. A disharmony in this area would also raise controversy across patient' organizations as it will become difficult to justify that in the framework of the European Union not all patients enjoy the same degree of health protection. However, in this subject of access and equity, not only regulators should be seen as the only responsible party. Industry also has a responsible role to play. Regulators and HTA bodies are taking important steps and efforts to harmonize criteria and are willing to embark in a transparent dialogue with industry to facilitate the development of new drugs. But at the same time, sponsors of the new medicines also need to be aware of the European governments' obligation to assure the long term sustainability of their health systems.

\section{REFERENCES}

1. EU Pharmaceutical informations. Eudralex Volume 1. Pharmaceutical Legislation Medicinal Products for Human Use. Available at: http://ec.europa.eu/health/documents/eudralex/vol-1/index_en.htm (last accessed October 2015)

2. European Network of Health Technology Assessment (EunetHTA). Available at: http://www.eunethta.eu/ (last accessed October 2015)

3. European Network of Health Technology Assessment (EunetHTA). HTA Core Model. Available at: http://www. eunethta.eu/hta-core-model (last accessed October 2015)

4. Berntgen M, Gourvil A, Pavlovic M, et al. Improving the Contribution of Regulatory Assessment Reports to Health Technology Assessments-A Collaboration between the European Medicines Agency and the European network for Health Technology Assessment. Value Health 2014; 17: 634-41; http://dx.doi.org/10.1016/j.jval.2014.04.006

5. Directive 2011/24/EU of the European Parliament and of the Council of 9 March 2011 on the application of patients' rights in cross-border healthcare. Available at: http://eur-lex.europa.eu/homepage.html (last accessed October 2015)

6. European Commission. Register of designated orphan medicinal products. Available at: http://ec.europa.eu/health/ documents/community-register/html/alforphreg.htm (last accessed October 2015)

7. European Medicines Agency. European public assessment report (EPAR) for Kalydeco. Available at: http://www. ema.europa.eu/ema/index.jsp?curl=pages/medicines/landing/epar_search.jsp\&mid=WC0b01ac058001d124 (last accessed October 2015)

8. Cohen D, Raftery J. Paying twice: question over high cost of cystic fibrosis drug developed with charitable funding. BMJ 2014; 348: 1445.

9. Kalydeco (ivacaftor). European Public Assessment Report. Available at: http://www.ema.europa.eu/docs/en_GB/document_library/EPAR_-_Summary_for_the_public/human/002494/WC500130744.pdf(last accessed October 2015)

10. Scottish Medicines Consortium (SMC): Ivacaftor 150mg film-coated tablets (Kalydeco). SMC No (827/12). Available at: https://www.scottishmedicines.org.uk/files/advice/ivacaftor_Kalydeco_FINAL_December_2012_amended_11_01_13_for_website.pdf (last accessed October 2015)

11. NHS Commission Board. Clinical Commissioning Policy: Ivacaftor for cystic fibrosis. Available at: http://www. england.nhs.uk/wp-content/uploads/2013/04/a01-p-b.pdf (last accessed October 2015)

12. Agencia Española de Medicamentos y Productos Sanitarios. Informe de Posicionamiento Terapéutico de Ivacaftor (Kalydeco). Available at: http://www.aemps.gob.es/medicamentosUsoHumano/informesPublicos/docs/IPT-ivakaftorkalydeco-aprobado-GCPT.pdf (last accessed October 2015)

13. Institut für Qualität und Wirtschaftlichkeit im Gesundheitswesen (IQWIG)- Ivacaftor (neues Anwendungsgebiet) - Bewertung gemäß. Available at: https://www.iqwig.de/download/G14-09_Ivacaftor-neues-Anwendungsgebiet_ Bewertung-35a-Abs1-Satz10-SGB-V.pdf (last accessed October 2015) 
14. National Centre for Pharmacoeconomics (NCPE). Ireland. Cost-effectiveness of Ivacaftor (Kalydeco) for the treatment of cystic fibrosis in patients aged 6 years an older who have the G551D mutation. Available at: http://www. ncpe.ie/wp-content/uploads/2012/08/Ivacaftor-Summary.pdf (last accessed October 2015)

15. Haute Autorité Santé. Transparency Committee. Kalydeco $150 \mathrm{mg}$ film-coated tablets. Available from: http://www. has-sante.fr/portail/upload/docs/application/pdf/2013-05/kalydeco_ct_12474.pdf (last accessed October 2015)

16. The Canadian Drug Expert Committee. Final CDEC Recommendation. Ivacaftor. Available from: http://www. cysticfibrosis.ca/wp-content/uploads/2013/09/CADTHKalydeco_March-25-13.pdf (last accessed October 2015)

17. Australian Government. Department of health. Public Summary Document. Ivacaftor. PBAC Meeting. Available at : http://www.pbs.gov.au/industry/listing/elements/pbac-meetings/psd/2014-03/ivacaftor-psd-03-2014.pdf (last accessed October 2015) 